\title{
Historical trends among cestode research of vertebrates in the Philippines
}

\author{
Vanessa V. Martinez $z^{1,2}$ and Jonathan Carlo A. Briones ${ }^{2,3,4,5^{*}}$
}

\begin{abstract}
The study of cestodology has provided an increased understanding of global parasite epidemiology and has contributed to the decrease of human health risks caused by parasite infections. Research trends over past decades have proven that more species have yet to be discovered. An analysis of the trend of cestode studies among vertebrates in the Philippines is hereby presented in aspects of (1) peer-reviewed readership, (2) host taxa studied, (3) geographical distribution, and (3) target parasite species of interest. A survey of 182 publications in primary scientific and grey literature from 1904 to 2017 revealed that most studies were published locally. Likewise, a number of papers favored mammals, particularly humans, as the preferred vertebrate host of study. Looking into geographical distribution, a great number of publications focused on Luzon Island and was concentrated in Manila. Cestode species reported so far in the country belong to order Cyclophyllidea, with Taenia solium and T. saginata as the preferred species to be investigated. Looking into these, we suggest that a shift into the application of molecular systematics and biotechnology would further develop Philippine cestode research, given that the historical trend has focused on parasite discovery, identity, and classification. May this paper be a call to further fill the gaps in what is known about cestodes and other parasites in the Philippines, given the country's potential for further discoveries.
\end{abstract}

KEYWORDS: Cyclophyllidea, parasite, Platyhelminthes, Taenia, tapeworm

\section{INTRODUCTION}

Helminth parasites were, at one time, a favored topic of research in the Philippines; however, little has been done in this field in the recent decade. This is of importance, since many of these organisms cause serious illness, both in humans and wildlife. Among various helminthic infections, cestodes occur less frequently than other helminthiases, but are also of interest because of their propensity to cause serious illness and clinical complications (Min, 1990). This is why it is important to look into the history of cestode research in the Philippines, in the context of temporal trends within a country-wide setting.

${ }^{1}$ Universidad de Manila, Ermita, Manila

${ }^{2}$ The Graduate School, ${ }^{3}$ Department of Biological Sciences of the College of Science, ${ }^{4}$ Research Center for the Natural and Applied Sciences, ${ }^{5}$ Educational Technology Center, University of Santo Tomas, Manila

*Corresponding email: jabriones@ust.edu.ph

Date Submitted: 01 December 2017

Date Accepted: 17 March 2018
In the Philippines, cestode research has been among the central theme of many parasite studies, but interest in this field has waned significantly. Scientists have studied cestodes in the country within the context of biodiversity, epidemiology, taxonomy, life cycles, and medical implications among vertebrate hosts (see Velasquez \& Eduardo, 1994). However, many of these have been limited to only one species or cestode group of interest per study, with a limited range of host types analyzed. Also, it is now evident that timely researches within this field have been but absent in the past decade (see Fox, 2008). In this paper, we intend to present a collective synthesis on cestode research in the country by analyzing historical trends from scattered primary and grey literature. Hereafter, we list down visible gaps in the scientific literature and provide recommendations on the current needs and future prospects of cestode research in the country.

We obtained data listings of cestodes from Philippine vertebrate hosts by data mining citations among published literature, as well as utilizing a variety of search engines, such as Google Scholar, PubMed, Science Open, and BioOne, to gather the appropriate scientific literature. From September to November 2017, we utilized these search 
engines to look for data entries that will match the following keywords: parasit* and Philippine*; cestod* and Philippine* (* corresponds to the singular, plural, and scientific versions of each keyword, e.g., cestode, cestodes, cestoda). In addition, we also summarized data from established listings of parasite researches from national book publications, such as Velasquez \& Eduardo (1994) and Eduardo (1997). These books have been a central repository of data related to parasite research in the country but are now in need of revision, given that the data provided are now at least two decades out of date. In tandem with the data review from these two landmark books, we also revisited articles from local journals that that do not have optimized websites for search engine visibility or are totally lacking in web presence (no website or central data hub for storage). We surveyed these journals from 1997 up to present, specifically data mining articles and citations that are related to cestode research. Data retrieved were classified under the following: (1) publication type (international or local; grey or primary literature), (2) taxon of vertebrate host, (3) geographic distribution covered, and (4) species of cestode studied.

\section{Summary of Cestode Literature in the Philippines}

A total of 182 data entries comprising both grey and primary literature were retrieved from the data mining strategy described above. From these, it is evident the publication trends for cestode research actually favor local readership, with a total of 105 studies published nationally in comparison to 33 internationally published primary researches from 1904 to 2000 (Fig. 1a). Interestingly, the earliest cestode researchers in the Philippines were not Filipinos, but rather Americans, namely H.M. Hallock (1904) and C.L. Foster (1906), who were U.S. Army doctors assigned to the country. They published records of Hymenolepis nana (recorded at the time as Taenia nana) in the Journal of the American Medical Association, a journal that began publishing in 1883. After these pioneering studies, it is important to note the contributions of Marcos A. Tubangui, a Filipino parasitologist from Porac, Pampanga, who contributed 11 primary national publications (in addition to 2 in the grey literature) from 1922 to 1947. According to our compilation, M.A. Tubangui published the most number of studies related to cestodes in the country (Fig. 2b). He graduated from the University of the Philippines' College of Veterinary Science with a D.V.M. degree in 1918, and earned a Master of Science degree in Science in 1921 from Cornell University, Ithaca, New York. On his return to the Philippines, he eventually became the Chairman of the Department of Veterinary Parasitology at the University of the Philippines (see Yutuc, 1951). His works on cestodes was extensive and included a variety of vertebrate hosts. Among these, he had reported five species of pseudophyllideans from the Philippines, resulting to the
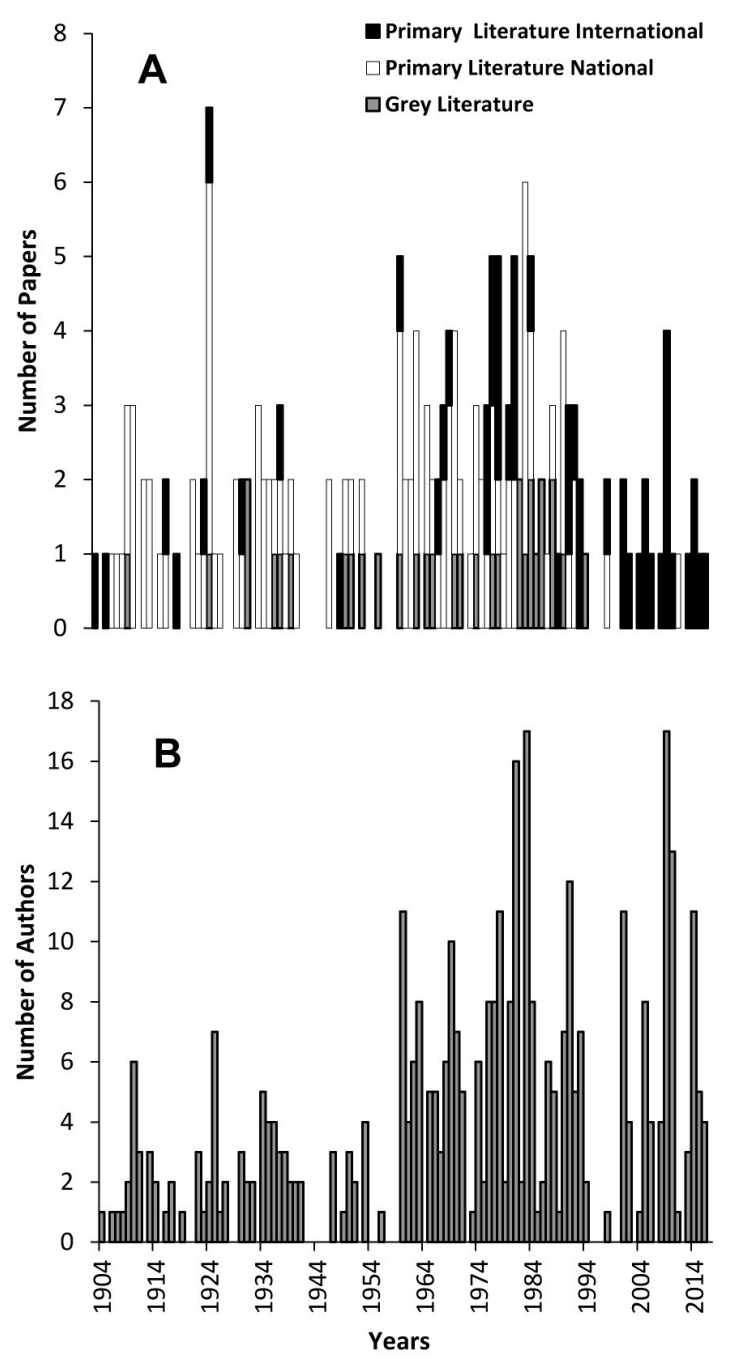

Figure 1. Yearly timeline of the publication history tackling cestode research in the Philippines. A: literature types subdivided into primary literature (national and international) and grey literature from conferences, terminal reports, and the like. B: total number of authors per year.

description of two new species, namely Scyphocephalus secundus, from the monitor lizard Varanus salvator, and Bothriocephalus travassosi from the eel Anguilla mauritiana (Tubangui, 1938). He also studied two tapeworm parasites from carabaos, which included a new species of Avitellina (Tubangui \& Farinas, 1930). He also described a new species (Oochorista exce/s) from the intestines of the grass lizard Mabuia multifasciata in Luzon (Tubangui \& Masilungan, 1936). His most notable work would be his report of 19 species of cestodes from birds in the Philippine islands, of which 15 were new to science and mostly $(n=8)$ belonging to the genus Raillietina (Tubangui \& Masilungan, 1937). The great majority of Tubangui's studies were published in the Philippine Journal of Science, which has been managed by the Department of Science and Technology (DOST) since 1906 and is currently published by DOST's Science and Technology Information Institute (Fig. 2a). 

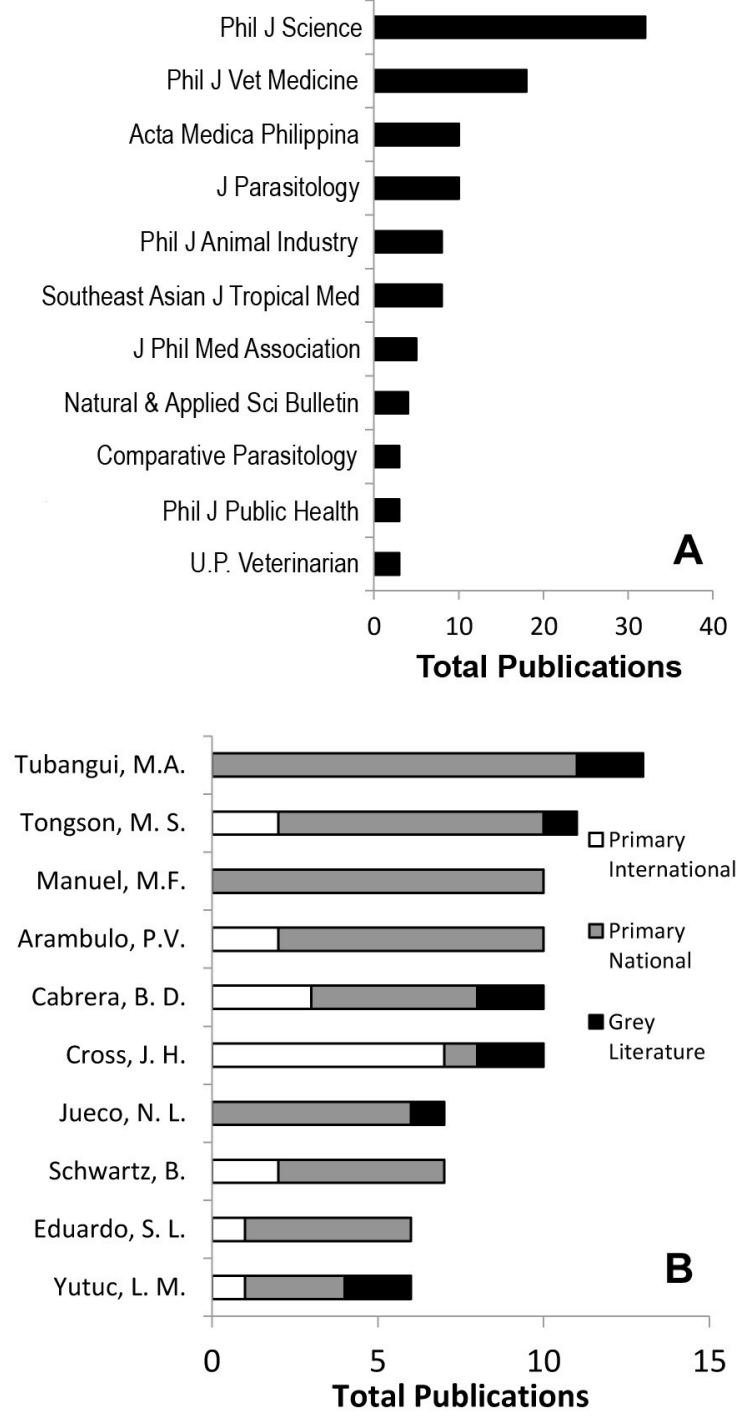

Figure 2. Top contributors of published cestode research in the Philippines. A: Top 10 journals wherein cestode research has been published. B: Top 10 author contributors.

We herein note that most effort put towards cestode research in the country took place from the 1960s up to the early 2000 s (Fig. 1a). It was during this "golden age" when the most number of publications (96) and the most number of scientists (218 authors and co-authors) were recorded. Within this period, local publications were still prominent (52 in the national literature), but this was also accompanied by a notable increase in international publications (24) and an increase in local discussions and forums (20 in the grey literature). However, the number of publications seems to have decreased two-fold in the recent decade, with only 21 publications recorded from 2001 to the present. This is perhaps due to a refocusing of efforts on publishing internationally (18 in international versus 3 in the national literature). We also note a potential increase in collaborative research wherein the number co-authors have increased within the last decade ( $n=218$ from 1960 to 2000 versus $n=82$ from 2001 to 2017). In the past, it was difficult to produce collaborative works among dispersed scientists/studies due to physical distance (similar sentiments by Kiesler \& Cummings, 2002; Allen, 1977). Today, dispersed collaborations have been made easier by modern communication technologies, which allow scientists to exchange resources like data, news, reports, instruments, and even equipment (see Finholt, 2002; Kouzes et al., 1996; Hesse et al., 1993).

\section{Variety of Studied Host Representatives}

From 1904 to the present, most of the published work on cestodes in the country had focused on mammalian hosts (155 of 182 studies) through biodiversity surveys (104 of 182 studies) (Fig. 3). This is not the case with other continents such as Australia, where most host groups studied represented more than one vertebrate taxon (Beveridge \& Jones, 2002). Within the context of this mammalian-centric cestode research, we observed a few temporal trends. Clinical research on humans was the primary trend during the 1900s and 2000s, followed by continuous research on parasites of veterinary importance involving domesticated mammals such as cats and dogs, and agricultural mammals like cattle, carabaos, goats, sheep, pigs, and horses. Only a few studies considered wildlife, most notably the palm civet (Tubangui, 1924), captive calamian deer (Eduardo et al., 1991), tapirs (Chin, 1938), monkeys (Africa, 1935), squirrels (Beveridge, 1989), and flying lemurs (Chu, 1931). That humans are the favored subject hosts may be attributed to the fact that anything that affects humans is of great interest for investigators and scientists; even the animals that were studied may have been chosen for their possible effects on humans, either as pets or sources of food and livelihood. In the Philippines, agricultural and farm animals are of primary importance not only for livelihood and crop production but also as a source of meat, a staple food item for most Filipinos. This is withstanding the fact that humans and other mammals serve as either the final or intermediate hosts of a wide variety of cestode species.

Starting in the 1960s up to the present, we observed an increased interest in studying cestodes among a wider variety of vertebrate hosts (Fig. 3). Parasite biodiversity surveys on birds $(n=14)$, fishes $(n=14)$, reptiles $(n=9)$, and amphibians $(n=3)$ were recorded within this period. It is interesting to note that in other developed countries such as China, biodiversity research among wildlife such as these is still considered lacking by local scientists (Gonghuang, 2013). The late onset of interest and scarcity of research among cestodes found in terrestrial vertebrates such as amphibians and reptilians in the country is not surprising and may be due to several reasons, such as the restricted 
distribution of many species of amphibians and reptilians as protected by wildlife laws, the low numbers or endangered status of some species, the lack of financial support, and, most commonly, the lack of interest among most investigators.

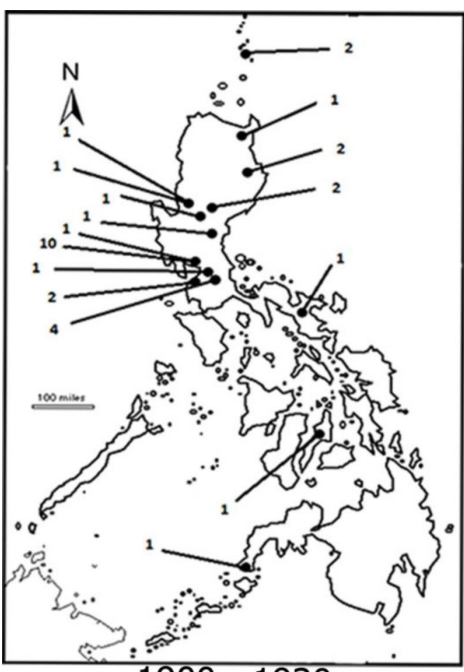

$1900-1930$

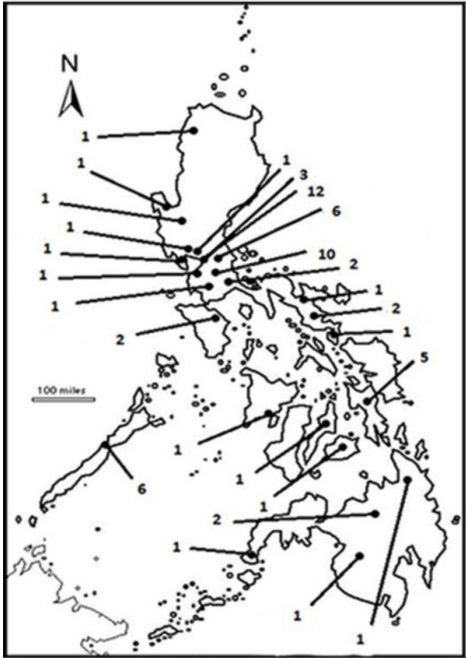

$1961-1990$

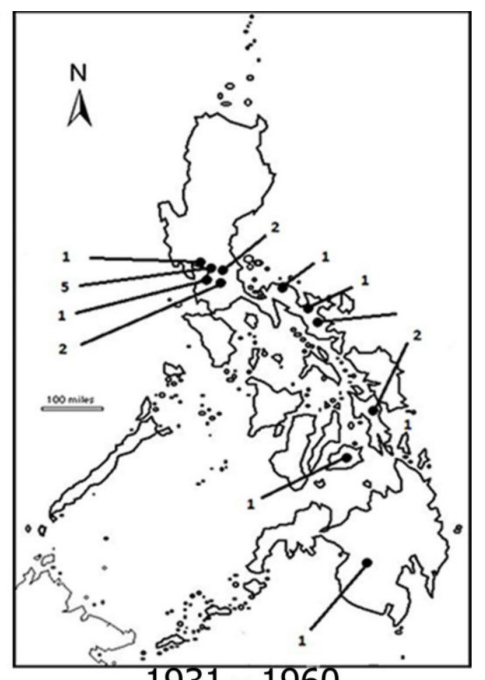

$1931-1960$

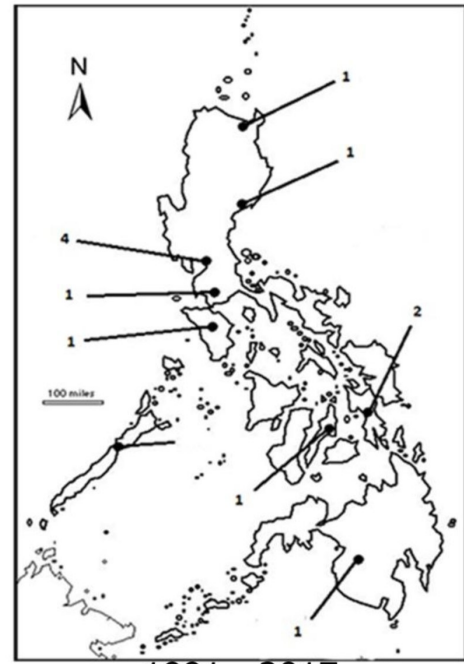

$1991-2017$
Figure 3. A decadal timeline snapshot of the geographical distribution of published cestode research in the Philippines.

Among aquatic vertebrates such as fish, most cestode studies involved freshwater species (Lopez, 1978; Velasquez, 1978; Lopez, 1988; Salcedo et al., 2009; Hanviripayant, 1977), particularly those in aquaculture (Kabata, 1985; Velasquez, 1986 \& 1988; Lopez, 1990), although there has also been few but notable research among important families of marine food fishes as well, specifically from the family Serranidae (Lopez, 1998) and family Belonidae (Palm et al., 1993). There has been no study yet on cestodes of elasmobranchs in the Philippines, which opens many opportunities for future collaborative research. This is because tapeworms that parasitize elasmobranchs represent considerable diversity: an estimate of at least 9 orders and 977 species in 201 genera
(Caira \& Jensen, 2014). For example, of the 43 species of elasmobranchs examined for parasites in the Gulf of California, at least 7 species (Rhinobatos productus, $R$. leucorhynchus, Myliobatis californicus, $M$. longirostris, Urobatis halleri, U. maculatus, and Rhinoptera steindachneri) were found to host diphyllidean cestodes, all belonging to Echinobothrium (Tyler, 2001). It is important as well to note that in recent years, cestode research has also included other varied research objectives, medical experimentation as one example, but majority of these were still within the context of biodiversity surveys of a certain kind. For example, medical surveys and experimental studies dealt mostly with the treatment of cestode infections of avian livestock (Reyes et al., 1974; Batolos et al., 1983; Manuel et al., 1983) and agricultural mammals (Dumag et al., 1963; Manuel et al., 1981; Tongson \& Montenegro, 1974).

\section{Timeline of the Geographic Distribution of Cestode Research}

The earliest accounts of cestode research in the Philippines (between the 1900s and 1930s) are concentrated in Luzon, mostly in Southern and Central Luzon, with sporadic records from the island's northern regions (Fig. 4). Manila, then the primary center of academic activities, was also the site for 10 studies during this period. Within three decades after (1931 to 1960), we can observe an increased spread of published cestode research scattered across the Philippines, from Central and Western Luzon down to the Visayas and Mindanao islands, although most studies were still being conducted in Manila. From the 1960s to 1990s, a growth in interest in cestode research is visible, but had decreased significantly from the 1990s to the present. Nevertheless, many of the recent studies have come from a wider area of coverage, albeit reduced in total number. Notable is the scarcity, if not the absence, of similar studies in areas in the northern parts of the country such as in Apayao, Kalinga, and the Mountain Province. A similar situation can be concluded for other islands in the Visayas such as Aklan, Antique, Capiz, Guimaras, Negros Occidental, Negros Oriental, Siquijor, and Northern and Eastern Samar, and also in most parts of Mindanao such as Misamis Occidental, Misamis Oriental, Lanao del Norte, Lanao del Sur, Maguindanao, South Cotobato, Sultan Kudarat, Compostela Valley, Misamis Occidental, Saranggani, Agusan del Sur, Surigao del Norte, Surigao del Sur, Basilan, Sulu, and Tawitawi. These areas could be target study sites from which researchers may be interested to tackle untapped and unexplored parasite-related investigations.

\section{Diversity of Cestode Species Studied}

From all the records retrieved, we recorded a total of $n=102$ cestode species reported in the Philippines, belonging to 

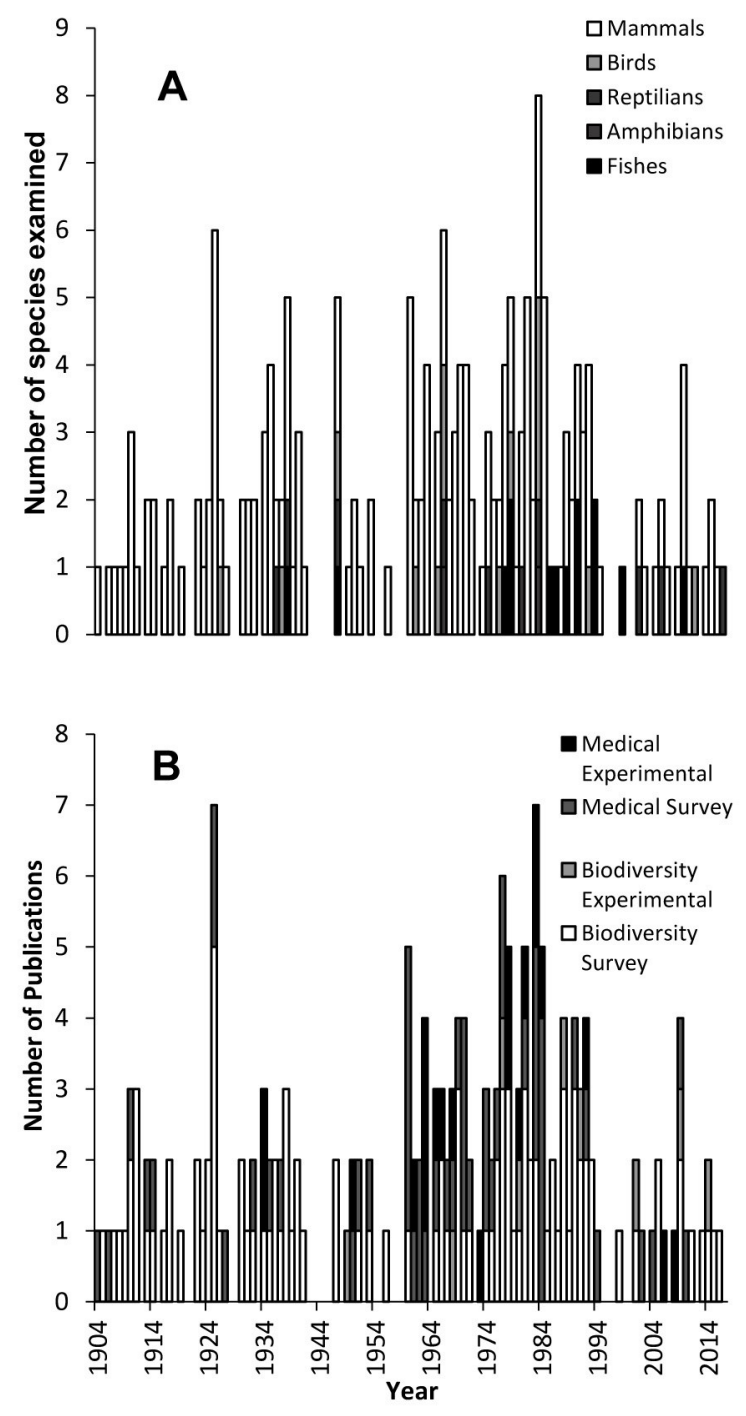

Figure 4. Timeline profile of the targets for cestode research in the country. A: vertebrate host taxa examined. B: research design employed.

seven orders (Table 1). This number is considerable less compared to other country-wide estimates reaching up to 400 species (see Cheng, 2002). This reiterates the opportunity to find undiscovered species in the country from future research opportunities. Majority of species recorded from the country are from order Cyclophyllidea, followed by Pseudophyllidea (comprising the modern orders Bothriocephalidea and Diphyllobothriidea in Table 1). This pattern of species taxa distribution is similar to that from other country-wide surveys (see Beveridge \& Jones, 2002). Taenia solium (Cyclophyllidea: Taeniidae) tops the list of species frequently studied in the Philippines with 4 biodiversity surveys, 5 medical surveys, and 7 medical experimental studies. Of these, almost half had focused on larval stages (cysticercus cellulosae). This is closely followed by Taenia saginata, with 16 studies mainly involved with medical experimentation, with only 1 biodiversity survey focused on its larval form (cysticercus bovis).
Looking into medical-related cestode research in the Philippines, it is important to reiterate that the morphology, life cycle, epidemiology, as well as pathogenicity are quite different for the most common human tapeworms studied in the country, namely Taenia solium and $T$. saginata. Human infections of these species are diagnosed through morphology of gravid proglottids, antibody detection, as well as DNA molecular techniques. In the case of $T$. solium, the main intermediate host are pigs, with humans getting infected through ingestion of raw or undercooked pork. In contrast, $T$. saginata is recorded to utilize cattle as intermediate/paratenic host. As for pathogenicity, the intestinal adult stage of both Taenia species usually does not exhibit pertinent symptoms. However, the inadvertent ingestion of eggs released by humans harboring this tapeworm does cause cysticercosis, developing mainly in the eyes, muscles, and the central nervous system (neurocysticercosis). There are approximately 50,000 annual deaths attributed to neurocysticercosis (Mafojane et al., 2003).

Taeniasis is currently the most prevalent cestode-related illness in many Asian countries like Korea, with cysticercosis caused by Taenia solium often revealing significant clinical manifestations (Min, 1990). Such a situation is not limited within the Asian continent, however, since cases have been found in as many as twelve of eighteen countries in Western Europe (Laranjo-González \& Devleesschauwer, 2017). From these, it is important to note that reported cases of larval cestodiasis have, in many instances, significantly affected the local economy of developing countries. When these are reported, there are often times a visible decrease in both the demand and supply of the country's meat and dairy products (Smyth, 1980), as government restrictions often arouse a negative reaction towards the consumption of meat taken from the animal farm industry. Concerning its control, the International Task Force for Disease Eradication (ITFDE) declared taeniasis-cysticercosis as "potentially eradicable" (Schantz et al., 1993). Taenia asiatica is third on the cestode species list frequently studied in the Philippines, along with Hymenolepis nana and Raillietina garrisoni (Table 1), all of which are under the order Cyclophyllidea. Taenia asiatica illustrates a $T$. saginata-like morphology, but a $T$. solium-like life cycle. There is currently no specific immunodiagnostic method available for $T$. asiatica, hereby limiting its current detection potential.

At present, molecular techniques are the only tools that are able distinguish the three aforementioned Taenia species, but this is not normally used in routine diagnostic and monitoring methods. This concern hereby brings to light possible questions on the definite geographic distribution and zoonotic potential of $T$. asiatica in the country, as it is 
Table 1. Summary table of names and classification of cestode species studied in the Philippines from 1904 up to present, with the total employed studies subdivided by research design. BS: biodiversity survey. BE: biodiversity experimentation. MS: medical survey. ME: medical experimentation. Number listed $(1,2,3, \ldots 9)$ correspond to the total number of research recorded. Color scale was included to emphasize an increase in total number (light grey to black: 1 to 9 ).

\begin{tabular}{|c|c|c|c|c|c|c|}
\hline Order & Family & Species Name & BS & $\mathrm{BE}$ & MS & ME \\
\hline \multirow[t]{2}{*}{ Bothriocephalidea } & Bothriocephalidae & Bothriocephalus travassosi & 2 & & & \\
\hline & & Schyzocotyle acheilognathi * & 3 & & & \\
\hline \multirow[t]{2}{*}{ Caryophyllidea } & Lytocestidae & Lytocestus birmanicus & 2 & & & \\
\hline & & Boviena serialis & 2 & & 1 & \\
\hline \multirow[t]{24}{*}{ Cyclophyllidea } & Anoplocephalidae & Anoplocephala mamillana & 1 & & & \\
\hline & & Anoplocephala perfoliata & 1 & & & \\
\hline & & Anoplocephala tapirus & 1 & & & \\
\hline & & Aporina delafondi & 1 & & & \\
\hline & & Aprostatandrya petauristae & 1 & & & \\
\hline & & Avitellina bubalinae & 1 & & & \\
\hline & & Bertiella boholensis & 2 & & & \\
\hline & & Bertiella elongata & 2 & & & \\
\hline & & Bertiella cynocephali & 2 & & & \\
\hline & & Bertiella musasabi & 1 & & & \\
\hline & & Bertiella plastica & 1 & & & \\
\hline & & Bertiella rauschi & 1 & & & \\
\hline & & Bertiella satyri & 1 & & & \\
\hline & & Bertiella studeri & 2 & & & \\
\hline & & Indotaenia indica & 1 & & & \\
\hline & & Monieza benedeni & & & & 1 \\
\hline & & Monieza expansa & 2 & & & \\
\hline & & Monieza planissima & 1 & & & \\
\hline & & Monieza trigonophora & 1 & & & \\
\hline & & Oochorista excelsa & 2 & & & \\
\hline & & Oochorista javaensis & 2 & & & \\
\hline & Davaineidae & Cotugnia ilocana & 1 & & & \\
\hline & & Cotugnia rimandoi & 1 & & & \\
\hline & & Davainea madagascariensis & 1 & & & \\
\hline
\end{tabular}

*previously listed in literature as Bothriocephalus acheilognathi but has now been revised. 
Philippine Journal of Systematic Biology | Martinez, V.V.M. \& Briones, J.C.A.: Cestode research of vertebrates in the Philippines

Table 1 (continued)

\begin{tabular}{|c|c|c|c|c|c|c|}
\hline Order & Family & Species Name & BS & BE & MS & ME \\
\hline Cyclophyllidea & Davaineidae & Raillietina asiatica & & & 1 & \\
\hline \multirow[t]{28}{*}{ (continued) } & (continued) & Raillietina bulbularum & 1 & & & \\
\hline & & Raillietina celebensis & & & 1 & \\
\hline & & Raillietina cesticillus & 1 & & & \\
\hline & & Raillietina cirroflexa & 1 & & & \\
\hline & & Raillietina coronea & 1 & & & \\
\hline & & Raillietina culiauana & 1 & & & \\
\hline & & Raillietina daetensis & 1 & & & \\
\hline & & Raillietina demerariensis & & & 1 & \\
\hline & & Raillietina echinobothrida & 1 & & 1 & \\
\hline & & Raillietina equatoriensis & & & 1 & \\
\hline & & Raillietina fischthali & 1 & & & \\
\hline & & Raillietina formosa & & & 1 & \\
\hline & & Raillietina garrisoni & 2 & 2 & 2 & \\
\hline & & Raillietina johri & 1 & & & \\
\hline & & Raillietina madagascariensis & & & 1 & \\
\hline & & Raillietina palawanensis & 1 & & & \\
\hline & & Raillietina passeriformicola & 1 & & & \\
\hline & & Raillietina quitensis & & & 1 & \\
\hline & & Raillietina sequens & 1 & & & \\
\hline & & Raillietina tetragona & 1 & & & \\
\hline & & Raillietina tinguiara & 1 & & & \\
\hline & & Raillietina torquota & 1 & & & \\
\hline & & Raillietina volzi & 1 & & & \\
\hline & Dilepididae & Kowalewskiella buzzardia & 1 & & & \\
\hline & Dipylidiidae & Dipylidium buencaminoi & 1 & & & \\
\hline & & Dipylidium caninum & 2 & 1 & 2 & \\
\hline & & Dipylidium halli & 1 & & & \\
\hline & Gryporhynchidae & Parvitaenia heckmanni & 1 & & & \\
\hline
\end{tabular}


Philippine Journal of Systematic Biology | Martinez, V.V.M. \& Briones, J.C.A.: Cestode research of vertebrates in the Philippines

Table 1 (continued)

\begin{tabular}{|c|c|c|c|c|c|c|}
\hline Order & Family & Species Name & BS & $\mathrm{BE}$ & MS & ME \\
\hline & Hymenolepididae & Allohymenolepis palawanensis & 1 & & & \\
\hline & & Diorchis visayana & 1 & & & \\
\hline & & Haploparaxis sanjuanensis & 1 & & & \\
\hline & & Hymenolepis alterna & 1 & & & \\
\hline & & Hymenolepis bicauda & 1 & & & \\
\hline & & Hymenolepis bilaterala & 1 & & & \\
\hline & & Hymenolepis corallis & 1 & & & \\
\hline & & Hymenolepis coronoidis & 1 & & & \\
\hline & & Hymenolepis diminuta & 3 & & & \\
\hline & & Hymenolepis haukisalmii & 1 & & & \\
\hline & & Hymenolepis nana & 3 & & 3 & \\
\hline & & Hymenolepis pycnonoti & 1 & & & \\
\hline & Paruterinidae & Anonchotaenia chauhani & 1 & & & \\
\hline & & Anonchotaenia gaugi & 1 & & & \\
\hline & Taeniidae & Echinococcus granulosus & 2 & & 1 & \\
\hline & & Taenia asiatica & 4 & 1 & & 1 \\
\hline & & Taenia philippina & 1 & & & \\
\hline & & Taenia saginata & 4 & & 5 & 7 \\
\hline & & Taenia solium & 5 & 1 & 9 & 7 \\
\hline & & Taenia taeniaformis & 3 & & & \\
\hline \multirow[t]{3}{*}{ Diphyllobothriidea } & Solenophoridae & Duthersia expansa & 1 & & & \\
\hline & & Duthersia fimbriata & 1 & & & \\
\hline & Diphyllobothriidae & Spirometra erinacei & & & 1 & \\
\hline \multirow[t]{6}{*}{ Onchoproteocephalidea 1} & Acanthotaeniinae & Acanthotaenia daileyi & 2 & & & \\
\hline & & Kapsulotaenia frezei & 1 & & & \\
\hline & Diphyllobothriidae & Diphyllobothrium erinacea & 1 & & 1 & \\
\hline & & Diphyllobothrium erinaceieuropaei & 2 & & 1 & 1 \\
\hline & & Diphyllobothrium latum & 2 & & & \\
\hline & & Diphyllobothrium mansoni & 1 & & 1 & \\
\hline
\end{tabular}


Table 1 (continued)

\begin{tabular}{|c|c|c|c|c|c|c|}
\hline Order & Family & Species Name & BS & BE & MS & ME \\
\hline & & Diphyllobothrium ranarum & & & 1 & \\
\hline & & Spirometra ranarum & & & & 1 \\
\hline & & Sparganum mansoni & & & 1 & \\
\hline & & Sparganum philippinensis & 1 & & & \\
\hline & & Bothridium pithonis & 3 & & & \\
\hline 'Tetraphyllidea' & incertae sedis * & Scolex polymorphus & 1 & & & \\
\hline \multirow[t]{4}{*}{ Trypanorhyncha } & Lacistorhynchidae & Callitetrarhynchus gracilis & 1 & & & \\
\hline & Otobothriidae & Otobothrium kurisi & 1 & & & \\
\hline & & Otobothrium penetrans & 2 & & & \\
\hline & Pterobothriidae & Pterobothrium hira & 1 & & & \\
\hline
\end{tabular}

*of uncertain placement; "Tetraphyllidea" is currently split into different orders but placement of larval form is impossible to ascertain.

one of the most neglected agent of human taeniasiscysticercosis (Galán-Puchades \& Fuentes, 2013). In a globaī range, the current distribution of $T$. asiatica is mostly from Asian countries like Taiwan, South Korea, Indonesia, Philippines, Thailand, South-Central China, Vietnam, Japan, and Nepal (Ale et al., 2014). The discovery of $T$. asiatica from Japan, Philippines, and Vietnam was made possible through molecular genotypic techniques (Eom et al., 2009).

Meanwhile, Hymenolepis nana (family Hymenolepididae) has been the parasite of choice for a number of biodiversity studies and medical surveys. Known as the dwarf tapeworm, it was first discovered in humans in Cairo, Egypt as early as 1851. At some instance, the Philippines was reported as an infection point for returning U.S. soldiers who may have acquired the parasite there (Deaderick, 1906). Raillietina garrisoni (family Davaineidei) was also of interest for Tubangui (1931) as he described and reported this tapeworm in brown rats (Rattus norvegicus) in Manila, with a relatively high prevalence (86\%). A follow-up study by Jueco \& Zabala (1990) six decades later recorded a significantly lower prevalence rate $(31.7 \%)$ from the same rat species collected from Manila and other provinces in Luzon. At present, $R$. garrisoni is regarded as the most common intestinal cestode infecting rodents (Jueco, 1983) and even children (Jueco, 1975) in the Philippines. In this case, both rodents and humans may become infected by ingestion of an arthropod intermediate host (Tribolium beetles) containing cysticercoid larva (Cruzada \& Jueco, 1998). In addition to $R$. garrisoni, a recent study on the parasite biodiversity in rats $(R$. norvegicus and $R$. rattus) caught in wet markets in Manila and Batangas also recorded Hymenolepis diminuta in the intestine and Taenia taeniaformis in the liver (Claveria et al., 2005).

Most of the species recorded in this study were from reviewed literature related to biodiversity surveys, representing a solid effort in discovering and identifying cestodes from a variety of vertebrate hosts. Even in recent years, records of cestode studies in the Philippines, Indonesia, and Malaysia have reported prevalence rates in humans and novel species listings from other animals (Makarikov et al., 2015; Goldberg et al., 2016). Within tropical Asia, there is essentially a scarcity of studies that utilize modern biotechnological methods (see Cross, 1988) although globally, the application of molecular and immunological techniques in tapeworm research has been gaining momentum in recent years. Some examples of such innovations are the generation of complete genomes for selected cestode species (Olson et al., 2012), the troubleshooting of molecular and immunological methods as complementary techniques for cestode detection (Ito, 2013), and the development of reliable PCR primers for cestode DNA amplification (Littlewood et al., 2008). There is no question that many of these studies will lead towards the novel understanding of cestode phylogenetics, as well as improvements on the diagnosis and clinical intervention of cestode infections of clinical and veterinary importance. It is 
then the responsibility of the present generation to attempt to apply these innovations in the Philippine setting, a task that hopefully will take root from previous research within tropical Asia (see Cross, 1989)

\section{CONCLUSION}

Cestode research in the Philippines has come a long way and, based on our estimates, still has great potential. By looking through these published studies in the context of the hosts, the parasite, the profile of authors, and geographic distribution, we confidently see a pattern of saturation in local readership. Although national readership is important, we see that further research published in a more regional or international setting may promote an increased interest within this field through interdisciplinary collaboration - the greatest challenge for scientists thus far. In the aspect of vertebrate hosts as the subject of cestode study, there are still more to explore especially with amphibians and reptiles, marine fishes, and other wildlife. We recommend that a shift of study areas be directed towards the Visayas and Mindanao regions, since most areas within these regions remain poorly studied with respect to cestodes. Since the prominent focus of Philippine cestode research had been on discovery and prevalence, a shift in approach may yield novel and uncharted study niches, wherein a venture into the application of molecular systematics and biotechnology would be a great opportunity. In summary, we hope this review will provide necessary insights and impetus for future research, to fill the gaps with much needed data, since there is still much more to explore in the field of cestodology in the Philippines.

\section{ACKNOWLEDGMENTS}

We are deeply grateful to $\mathrm{Dr}$. Anindo Choudhury and an anonymous reviewer, both of which provided extensive revisions, suggestions, and comments that have definitely improved this paper.

\section{LITERATURE CITED}

Africa, C.M. \& E.Y. Garcia, 1935. The occurrence of Bertiella in man, monkey and dog in the Philippines. Philippine Journal of Science, 56(1): 1-11.

Ale, A., B. Victor, N. Praet, S. Gabriël, N. Speybroeck, P. Dorny \& B. Devleesschauwer, 2014. Epidemiology and genetic diversity of Taenia asiatica: a systematic review. Parasites \& Vectors, 7: 45.

Allen, T., 1977. Managing the flow of technology. Cambridge, MA: MIT Press.

Batolos, J.A., C.E. Gajudo \& E.P. Mercado, 1983. Critical Evaluation of febantel against gastro-intestinal helminths of native chickens. Philippine Journal of Animal Industry,
38(1-2): 63-69.

Beveridge, I., 1989. Species of Bertiella (Cestoda: Anoplocephalidae) in dermopterans and squirrels from South-East Asia. Systematic Parasitology, 14(1): 1-15.

Beveridge, I. \& M.K. Jones, 2002. Diversity and biogeographical relationships of the Australian cestode fauna. International Journal for Parasitology, 32(3): 34351.

Caira, J.N. \& K. Jensen, 2014. A digest of elasmobrach tapeworms. Journal of Parasitology, 100(4): 373-391.

Cheng, G.H., 2002. Studies on the cestodes in China. China Women Publishing House, Beijing.

Chin, T.G., 1938. A new species of cestode of the family Anoplocephalidae (Cestoda) from tapir. Lingnan Science Journal, 17(4): 605-607.

Chu, H.J., 1931. Bertiella elongate Bourquin, 1905 and $B$. studeri Blanchard, 1891 from flying lemurs in the Philippine Islands. National Medical Journal of China, 17 (4-5): 488-492.

Claveria, F.G., J. Causapin, M.A. de Guzman, M.G. Toledo \& C. Salibay, 2005. Parasite biodiversity in Rattus spp caught in wet markets. The Southeast Asian Journal of Tropical Medicine and Public Health, 36(4): 146-148.

Cross, J.H., 1988. Biotechnology Research on cestodes in the Philippines, Malaysia and Indonesia. The Southeast Asian Journal of tropical Medicine and Public Health, 19 (1): 41-45.

Cross, J.H., 1989. The Application of Biotechnology to the study of cestodes. Buletin Penelitian Kesehatan, 17(2): 67-73

Cruzada, S.F. \& N.L. Jueco. 1988. Tribolium castaneum (the flour beetle) as intermediate host of the rat tapeworm, Raillietina garrisoni. Acta Medica Philippina, Series 2, 24 (3): 83-84.

Deaderick, W.H., 1906. Hymenolepis nana and Hymenolepis diminuta, with report of cases. The Journal of the American Medical Association, 47(25): 2087-2090.

Dumag, P.U. \& P.V. Reyes, 1963. The anthehelminthic efficacy of thiobendazole against gastro-intestinal parasites of cattle. Philippine Journal of Animal Industry, 24(1-4): 1-9.

Eduardo, S.L., I. Neri, M.V.A. Bravo \& L. Villamor, 1991. Notes on parasites of captive calamian deer, Cervus (Axis) calamianensis (Artiodactyla: Ruminantia). Philippine Journal of Veterinary Medicine, 18(2): 61-64.

Eduardo, S.L., 1997. A guide to the collections of the Philippine type-specimens of parasitic protozoa, helminths, and arthropods. National Academy of Science and Technology, Bicutan, Philippines.

Eom, K.S., H.K. Jeon \& H.J. Rim, 2009. Geographical Distribution of Taenia asiatica and Related Species. Korean Journal of Parasitology, 117: 115-124.

Finholt, T. A., 2002. Collaboratories. Annual Review of 
Information Science and Technology, 36: 73-107

Foster, C.L., 1906. Two cases of infection with Taenia nana in the Philippine Islands. Journal of the American Medical Association, 47(9): 685-686.

Fox, N., 2008. Review on the epidemiological profile of helminthiases and their control in the Western Pacific Region, 1997-2008, Western Pacific Regional Office of World Health Organization.

Galan-Puchadez, M.T. \& M.V. Fuentes, 2013. Taenia asiatica: The Most Neglected Human Taenia and the Possibility of Cysticercosis. Korean Journal of Parasitology, 51(1): 51-54.

Goldberg, S.R., C.R. Bursey, C.D. Siler \& R. M. Brown, 2016. Gastrointestinal helminths of two gekkonid species, Cyrtodactylus philippinicus and Gekko mindorensis (Squamata: Gekkonidae) from the Philippines. Comparative Parasitology, 83(1): 130-133.

Gonghuang, C., 2013. The studies on cestodes in China. Journal of Veterinary Science Technology, 5:1.

Hallock, H.M., 1904. Taenia nana: Report of two cases. Journal of the American Medical Association, 42(14): 891.

Hanviripayant, L., 1977. Helminthiasis in Clarias macrocephalus Gunther, 1864 with histological and histochemical observations of Orientocreadium batrachoides Tubangui 1931. Fisheries Research Journal of the Philippines, 2(2): 7-39.

Hesse, B.W., L.S. Sproull, S.B. Kiesler \& J.P. Walsh, 1993. Returns to science: Computer networks and scientific research in oceanography. Communications of the ACM, 36(8): 90-101.

Ito, A., 2013. Nothing is perfect! Trouble-shooting in immunological and molecular studies of cestode infections. Parasitology, 140: 1551-1565.

Jueco, N.L., 1975. Raillietina (a rat tapeworm) infection in young children in the Philippines. Acta Medica Philippina, Series 2, 11(2): 49-50.

Jueco, N.L., 1983. Rodent diseases transmissible to man. Acta Medica Philippina, Series 2, 19(4): 164-169.

Jueco, N.L. \& Z.R. Zabala, 1990. The cestodes and trematodes of Rattus norvegicus and Rattus rattus mindanensis. Philippine Journal of Veterinary Medicine, 27(2): 47-51.

Kabata, Z., 1985. Parasites and diseases of fish cultured in the tropics. Taylor \& Francis: London \& Philadelphia, p. 305.

Kiesler, S. \& J. Cummings, 2002. Distributed work. (Cambridge, MA:MIT Press): 57-90.

Kouzes, R.T., J.D. Meyers \& W.A. Wulf, 1996. Collaboratories: Doing science in the internet. IEEE Computer, 29(8): 40-46.

Laranjo-Gonzalez, M. \& B. Devleesschauwer, 2017. Geographical Distribution of Taenia asiatica and related species. Korean Journal of Parasitology, 47: 115-124.
Littlewood, D.T.J., A. Waeschenbach \& P.V. Nikolov, 2008. In search of mitochondrial markers for resolving the phylogeny of cyclophyllidean tapeworms (Platyhelminthes, Cestoda) - A test study with Davaineidae. Acta Parasitologica, 53(2): 133-144.

Lopez, N., 1978. Intestinal helminthiasis of Glossogobius giurus (Hamilton-Buchanan) from Tadlak Lake, Los Baños, Laguna Province, Philippines. Fisheries Research Journal of the Philippines, 3(1): 74-99.

Lopez, N.C., 1988. Helminth and arthropod parasites of some freshwater fishes from Laguna Lake and vicinities. In: Fish Health Problems in Laguna Bay and Environs, PCARRD Book Series No. 49/1988, Pp. 7-14.

Lopez, N.C., 1990. Blood values of some helminth-infected aquacultured fishes. Science Diliman, 3: 8-33.

Lopez, N.C., 1998. Parasites of some serranid fishes from Manila Bay (Philippines) (1998). Philippine Scientist, 35: 43-48.

Mafojane, N.A., C.C. Appleton, R.C. Krecek, L.M. Michael \& A.L. Willingham, 2003. The current status of neurocysticercosis in eastern and southern Africa. Acta Tropica, 87: 25-33.

Makarikov, A. A., V.V. Tkach, S.M. Villa \& S.E. Bush, 2015. Description of two new species of Hymenolepis Weinland, 1858 (Cestoda; Hymenolepididae) from rodents on Luzon Island, Philippines. Systematic Parasitology, 90: 27-37.

Manuel, M.F., D.B. Cantiller, W.R. Camero \& R.V. Dominguez, 1981. The anthelminthic efficacy of oxfendazole against gastrointestinal helminths of cattle and carabaos. Philippine Journal of Veterinary Medicine, 20(1):80-86.

Manuel, M.F. \& L.L. Gale, 1983. The Efficacy of Oxfendazole and Albendazole against Oxyspirura mansoni and other helminths of chickens. Philippine Journal of Animal Industry, 38(3-4): 1-13.

Min, D.Y., 1990. Cestode Infections in Korea. The Korean Journal of Parasitology, 28: 123-144.

Olson, P.D., M. Zarowiecki, F. Kiss \& K. Brehm, 2012. Cestode genomics - Progress and prospects for advancing basic and applied aspects of flatworm biology. Parasite Immunology, 34: 130-150

Palm, H., H. Moller \& F. Petersen, 1993. Otobothrium penetrans (Cestoda; Trypanorhyncha) in the flesh of belonid fish from Philippine waters. International Journal for Parasitology, 23(6): 749-755.

Reyes, P.V. \& R.S. Sumajit, 1974. Further studies on the use of atrabine as taenifuge against poultry tapeworms. A.U. Veterinary Digest, 5(6): 19-22.

Salcedo, N.B., E.A. Gonzaga, R.J. Garduque, V.B. Jimenez \& T.S. Panes, 2009. Detection of common parasites in freshwater fish sold at the Public Market, Kabacan, Cotabato. Philippines. USM R \& D Journal, 17(2): 147- 
149.

Schantz, P.M., M. Cruz, E. Sarti \& Z. Pawlowski, 1993. Potential eradicability of taeniasis and cysticercosis. Bulletin of the Pan American Health Organization, 27: 397 $-403$.

Smyth, J.D., 1980. Importance of larval cestodiasis to man in developing countries. In: Wood, C. \& Y. Rue (eds.), Health policies in developing countries. International Congress and Symposium Series, No. 24. Royal Society of Medicine, London, England, Pp. 97-102.

Tongson, M.S. \& M.M. Montenegro, 1974. Field study of purified microfine phenothiazine with lead arsenate in native goats. Philippine Journal of Veterinary Medicine, 13 (1-2): 170-182.

Tubangui, M.A., 1924. Two larval parasites from the Philippine palm civet (Paradoxurus philippinensis). Philippine Journal of Science, 24(6): 749-755.

Tubangui, M.A. \& E.C. Farinas. 1930. Two tapeworm parasites from the carabao, with special reference to a new species of Avitellina. Philippine Journal of Agriculture, 1(4): 421-429.

Tubangui, M.A., 1931. Worm parasites of brown rat (Mus norvegicus) in the Philippine Islands, with special reference to those forms that may be transmitted to human beings. Philippine Journal of Science, 46(4): 537591.

Tubangui, M.A. \& V.A. Masilungan, 1936. Oochorista excelsa, a new reptilian cestode. Philippine Journal of Science, 61 (1): 75-79.

Tubangui, M.A. \& V.A. Masilungan, 1937. Tapeworm parasites of Philippine birds. Philippine Journal of Science, 62(4): 409-438.

Tubangui, M.A., 1938. Pseudophyllidean cestodes occurring in the Philippines. Livro Jubilar Prof. Travassos, Rio de Janeiro, Brasil. Pp. 489-494.

Tyler, G.A., 2001. Diphyllidean Cestodes of the Gulf of California, Mexico with descriptions of two new species of Echinobothrium (Cestoda: Diphyllidea). Journal of Parasitology, 87(1): 173-184.

Velasquez, C.C., 1978. Cestodes of fresh water fishes from the Philippines. Proceedings of the Fifth International Congress of Parasitology (7-14 August, 1982), Molecular and Biochemical Parasitology, Supplement, Toronto, Canada. p. 311 (abstract).

Velasquez, C.C., 1986. Fish parasitology and aquaculture management in the Philippines. In: State-of-the-Art Papers, Biological Sciences, National Academy of Science and Technology, Philippines. Pp. 105-159.

Velasquez, C.C., 1988. Fish parasitology and aquaculture management in the Philippines. In: Fish Health Problems in Laguna de Bay and Environs, PCARRD Book Series no. 49/1988. Pp.15-29.

Velasquez, C.C. \& S.L. Eduardo, 1994. Index Catalogue of
Parasites of Philippine Vertebrates. National Academy of Science and Technology, Bicutan, Taguig. P. 391.

Yutuc, L.M., 1951. Marcos A. Tubangui (1893-1949). The Journal of Parasitology, 37 (5): 515-517. 